\title{
Chromosomal organization of retrotransposon Rex1 in Astyanax species (Characiformes, Characidae)
}

Gabriela Pessenda, Diovani Piscor, Edson L. da Silva, Liano Centofante \& Patricia P. Parise-Maltempi

To cite this article: Gabriela Pessenda, Diovani Piscor, Edson L. da Silva, Liano Centofante \& Patricia P. Parise-Maltempi (2018) Chromosomal organization of retrotransposon Rex1 in Astyanax species (Characiformes, Characidae), Caryologia, 71:1, 80-84, DOI: 10.1080/00087114.2017.1420588

To link to this article: https://doi.org/10.1080/00087114.2017.1420588

曲 Published online: 02 Feb 2018.

Submit your article to this journal $₫$

Џ Article views: 35

View Crossmark data ¿ 


\title{
Chromosomal organization of retrotransposon Rex1 in Astyanax species (Characiformes, Characidae)
}

\author{
Gabriela Pessendaa, Diovani Piscor ${ }^{\mathrm{a}}$, Edson L. da Silva ${ }^{\mathrm{a}, \mathrm{c}}$, Liano Centofante ${ }^{\mathrm{b}}$ and Patricia P. Parise-Maltempi ${ }^{\mathrm{a}}$ \\ anstituto de Biociências, Departamento de Biologia, Laboratório de Citogenética, Universidade Estadual Paulista "Júlio de Mesquita Filho" \\ (UNESP), Rio Claro, Brazil; ' Instituto de Biociências, Departamento de Biologia e Zoologia, Laboratório de Genética Animal, Universidade \\ Federal de Mato Grosso (UFMT), Cuiabá, Brazil; Instituto Federal de Educação, Ciência e Tecnologia do Piauí (IFPI), Laboratório de Biologia, \\ Picos, Brazil
}

\begin{abstract}
The cytogenetic studies of retrotranposons Rex have been characterized in several fish groups, including species of the Astyanax genus. This group presents an extensive variability in their karyotype, with diploid numbers of $2 n=52,50,48,46$ and 36 chromosomes. Thus, the aim of this study was to evaluate the distribution of the retrotransposable element Rex 1 , in six Astyanax species, with different diploid numbers. The species analyzed were Astyanax altiparanae $(2 n=$ $50)$, Astyanax asuncionensis $(2 n=50)$, Astyanax eigenmanniorum $(2 n=50)$, Astyanax marionae $(2 n=48)$, Astyanax fasciatus $(2 n=46)$ and Astyanax schubarti $(2 n=36)$. Rex 1 was dispersed in the Astyanax species, suggesting that these retrotransposons play important role in genome evolution.
\end{abstract}

\section{ARTICLE HISTORY}

Received 23 October 2017 Accepted 20 December 2017

\section{KEYWORDS}

Repetitive DNA; Karyotype diversity; Neotropical fish; Evolution

\section{Introduction}

The transposable elements are repetitive sequences (i.e., include the transposons and retrotransposons) that can change position within the genome, resulting in structural alterations, e.g. deletions or duplications. These sequences are also called jumping genes (Kazazian and Moran 1998; Biemont and Vieira 2006) and their importance as sources of genetic variations have been important for the evolution of the genomic structure and gene function in vertebrates and other organisms (Feschotte and Pritham 2007).

The retrotransposons encode a reverse transcriptase that acts on the reverse transcription of RNA transcripts into cDNA, resulting in the production of new copies of these elements. They are classified in two groups, according to the presence or absence of long terminal repeats (LTR) (Bohne et al. 2008). Between the non-LTR retrotransposons are Rex1, Rex3 and Rex6, which are absent from mouse and human genomes, but participated in the evolution of teleost fish (Volff et al. 1999, 2000, 2001, 2003).

Given the important roles of retrotransposable elements on fish evolution, their mapping is very important for understanding the genome structure and evolution process in Astyanax (Characiformes, Characidae) genus (Silva et al. 2013, 2014; Daniel et al. 2015;. Astyanax is an interesting group because present high karyotype diversity, including species with $2 n=52,50,48,46$ and 36 chromosomes (Tenório et al. 2013; Piscor et al.
2015; Nishiyama et al. 2016; Piscor et al. 2016; Piscor and Parise-Maltempi 2016a, 2016b).

Thus, considering the chromosomal variability found on Astyanax group, the aim of this study was to map the location of retrotransposable element (Rex1) in six Astyanax species with different diploid numbers, in order to verify the distribution pattern in the genome of this group.

\section{Materials and methods}

\section{Sampling}

Samples of six species of Astyanax genus were employed: A. altiparanae, $A$. asuncionensis, $A$. eigenmanniorum, A. fasciatus, A. marionae and A. schubarti. A. altiparanae and $A$. fasciatus were collected on the Ribeirão Claro river (São Paulo state (SP), Brazil), A. schubarti on Piracicaba river (SP, Brazil), A. marionae on Rio Claro stream (Mato Grosso (MT), Brazil), A. asuncionensis on Bento Gomes river (MT, Brazil) and A. eigenmanniorum was obtained from aquaria in Brazil. The cytogenetic preparations were obtained according to methodology described by Foresti et al. (1993).

\section{DNA extraction and sequence analysis}

Genomic DNA was extracted from fin and liver samples of Astyanax species, employing the phenol-chloroform-isoamyl alcohol technique (Sambrook and Russell 
2001). Amplification of Rex 1 sequences were performed by polymerase chain reaction (PCR), in a reaction containing $12.5 \mu$ l of PCR mix (Qiagen, Hilden, Germany), 1 $\mu \mathrm{l}$ of each primer $(10 \mathrm{mM}), 8.5 \mu \mathrm{l}$ of Milli-Q water and 2 $\mu \mathrm{l}$ of genomic DNA (400 ng). Specific primers used were: Rex1As $\mathrm{F}$ - 5'CCT GGA TCA CTG ACT ACC T and Rex1As $\mathrm{R}-5^{\prime} \mathrm{CAC}$ ACC AAG GTA TTT GTA GG. The PCR reaction followed the general conditions of initial denaturation at $95^{\circ} \mathrm{C}$ for $5 \mathrm{~min}, 34$ cycles of denaturation at $95^{\circ} \mathrm{C}$ for $40 \mathrm{~s}$, annealing at $55^{\circ} \mathrm{C}$ for $40 \mathrm{~s}$, elongation at $72^{\circ} \mathrm{C}$ for $5 \mathrm{~min}$, and final extension at $72^{\circ} \mathrm{C}$ for $5 \mathrm{~min}$, with final temperature maintained at $12^{\circ} \mathrm{C}$.

The PCR products were purified using ExoSAP-IT (GE Healthcare ${ }^{\mathrm{TM}}$, Chigado, IL, USA), and sequenced by MacroGen (Geumcheon-gu, Korea). The nucleotide sequences were aligned and edited with BioEdit Sequence Alignment Editor software (Hall 1999), sequenced, and deposited in GenBank with the accession numbers: MG793236 to MG793240.

\section{Fluorescence in situ hybridization (FISH)}

The FISH experiments were performed according to Pinkel et al. (1986) with modifications described by Cabral-de-Mello et al. (2010). Briefly, Rex1 sequences were labeled by PCR with biotin-16-UTP or digoxigenin-11-dUTP (Roche, Basel, Switzerland). Mitotic preparations on glass slides were treated with pepsin $\left(10 \mu \mathrm{g}^{\mathrm{ml}-1}\right)$ for $10 \mathrm{~min}$, and RNAse $\left(100 \mu \mathrm{g}^{\mathrm{ml}-1}\right)$ for $1 \mathrm{~h}$, in a moist chamber at $37^{\circ} \mathrm{C}$. The slides were dehydrated in 70, 90 and $100 \%$ ethanol for $5 \mathrm{~min}$ and air-dried. Subsequently, chromosomes were denatured in $70 \%$ formamide (in $2 \times \mathrm{SSC}$ ) for $2 \mathrm{~min}$ at $70^{\circ} \mathrm{C}$. The slides were denatured in cold 70, 90 and 100\% ethanol and hybridization was performed with Rex1 labelled with biotin-16-UTP or digoxigenin-11-dUTP for $45 \mathrm{~min}$ in a moist chamber at $37^{\circ} \mathrm{C}$. The detection of biotin labeled probes was performed with avidin-FITC conjugate (Sigma, St Louis, MO, USA), and the digoxigenin-labeled probes were detected with anti-digoxigenin-Rhodamine (Roche, Basel, Switzerland). The slides were mounted with DAPI and mounted with Vectashield (Vector, Burlingame, CA, USA), and the metaphases were photographed with the digital capture system Olympus model D71/DP Controller software.

\section{Results}

This study is a continuation of previous publications from our group (Piscor et al. 2015, 2016; Piscor and Parise-Maltempi 2016a, 2016b). Amplification of Rex1 sequences from Astyanax species resulted in fragments of approximately $600 \mathrm{bp}$ for all the samples analyzed.

The Astyanax species exhibited $2 n=50$ for A. altiparanae, $A$. asuncionensis and A. eigenmanniorum, $2 n=48$ for A. marionae, $2 n=46$ for A. fasciatus, and $2 n$ $=36$ for $A$. schubarti (Figure 1). The FISH experiments demonstrated a dispersed chromosomal distribution of Rexl sequences through the chromosomes of the analyzed species (Figure 1).

\section{Discussion}

The repetitive sequences have several distribution patterns among different fish groups. Our results demonstrated that Rexl elements present a dispersed pattern through the chromosomes of all species analyzed in this paper.

Other studies have already reported the distribution of retrotransposable elements in the chromosomes of species from Astyanax genus (Pansonato-Alves et al. 2013; Silva et al. 2013, 2014; Daniel et al. 2015) (Table 1). Similar to our data, Rex1 presented a dispersed pattern of distribution in A. paranae (Silva et al. 2014). On the other hand, Rex3 sites had co-location with heterochromatic blocks of this species (Silva et al. 2014). According to Pansonato-Alves et al. (2013), two A. fasciatus karyomorphs (A with $2 n=46$ and B with $2 n=48$ chromosomes) exhibited Rex3 elements on clusters on terminal positions of long arms (Pansonato-Alves et al. 2013). It was suggested that the variations in the heterochromatin distribution might be directly related to the evolutionary dynamics of mobile sequences, which could explain some different Rex3/heterochromatic blocks between karyomorphs A and B (Pansonato-Alves et al. 2013).

Rex3 clusters have also been observed co-located with heterochromatic blocks and $18 \mathrm{~S}$ rDNA sites, in two Astyanax bockmanni populations, from Capivara River, Tietê River basin and Água da Madalena Stream, Paranapanema River basin, Brazil (Silva et al. 2013). In this species, the co-location of Rex3 and $18 \mathrm{~S}$ rDNA sites, in some chromosomes, arises as a main mechanism of major rDNA dispersion and could be an alternative to explain the high index of polymorphisms of these regions (Silva et al. 2013).

It was previously demonstrated that Rex 1 distribution varies according to species in the Leporinus genus (also in the Characiformes order, but from the Anostomidae family). It was found dispersed throughout the chromosomes from L. friderici, L. lacustris, and L. striatus species, and in isolated clusters in terminal sites of chromosomes from L. elongatus, L. macrocephalus, and L. obtusiden, with signals in the interstitial region of the W sex chromosome (Borba et al. 2013). On the other hand, Rex3 had the same distribution pattern in all species, showing terminal isolated clusters and dispersed signals (Borba et al. 2013).

In species of Antarctic fishes belonging to Notothenioidei suborder, Rex 1 did not present a clear pattern of distribution, and generally was less abundant than Rex3, which showed a homogeneous distribution over the chromosomes, with accumulations in some regions (Ozouf-Costaz et al. 2004). In species of the Hypoptopomatinae subfamily, Rex 1 and $\operatorname{Rex} 3$ have been 


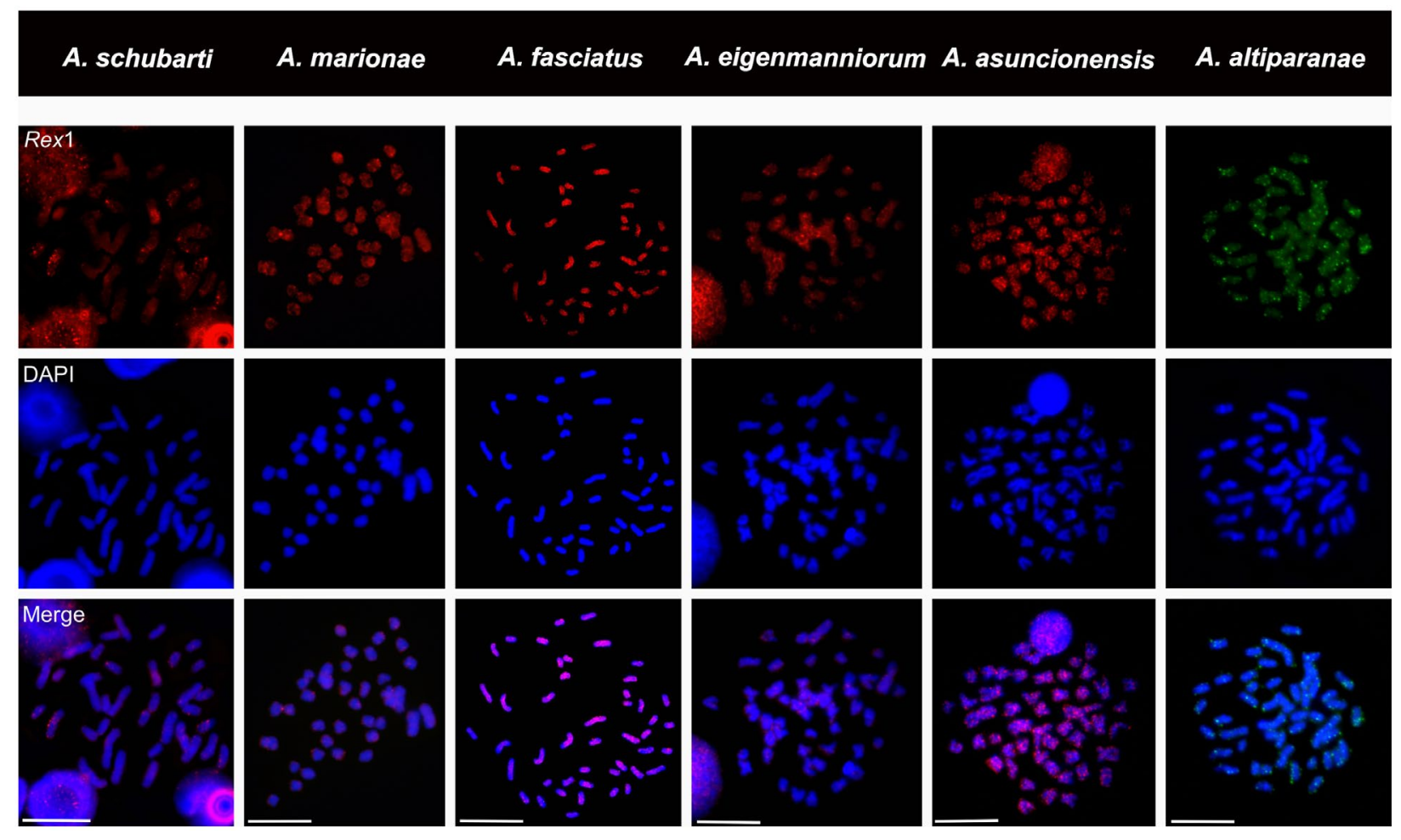

Figure 1. Chromosomal distribution of Rex 1 in Astyanax species with different diploid numbers. Bars $=10 \mu \mathrm{m}$.

Table 1. Chromosomal mapping of retrotransposable Rex elements distribution in Astyanax genus.

\begin{tabular}{|c|c|c|c|c|c|}
\hline Species & Localities/states & $2 n$ & Rex types & Rex distribution & Ref.* \\
\hline A. fasciatus Kary. A & Tietê river (SP) & 46 & $\operatorname{Rex3}$ & Clustered & 1 \\
\hline A. fasciatus Kary. B & Tietê river (SP) & 48 & $\operatorname{Rex} 3$ & Clustered & 1 \\
\hline \multirow{2}{*}{ A. bockmanni } & Capivara river (SP) & 50 & $\operatorname{Rex} 3$ & Clustered & 2 \\
\hline & $\begin{array}{l}\text { Água da Madalena stream } \\
\text { (SP) }\end{array}$ & 50 & $\operatorname{Rex} 3$ & Clustered & 2 \\
\hline \multirow[t]{2}{*}{ A. paranae } & Capivara river (SP) & $50+B$ & $\operatorname{Rex3}$ & Clustered & 3 \\
\hline & Capivara river (SP) & $50+B$ & $\operatorname{Rex} 1$ & Scattered & 3 \\
\hline \multirow[t]{10}{*}{ A. bockmanni } & Alambari stream (SP) & $50+B$ & $\operatorname{Rex} 1 / \operatorname{Rex} 3 / \operatorname{Rex} 6$ & Dispersed & 4 \\
\hline & $\begin{array}{l}\text { Véu de Noiva waterfall } \\
\text { (SP) }\end{array}$ & 50 & $\operatorname{Rex} 1 / \operatorname{Rex} 6$ & Dispersed & 4 \\
\hline & & & $\operatorname{Rex} 3$ & Clustered & 4 \\
\hline & Batalha river (SP) & 50 & $\operatorname{Rex} 1 / \operatorname{Rex} 6$ & Dispersed & 4 \\
\hline & & & Rex3 & Clustered & 4 \\
\hline & Campo Novo stream (SP) & 50 & $\operatorname{Rex} 1 / \operatorname{Rex} 3 / \operatorname{Rex} 6$ & Dispersed & 4 \\
\hline & Barra Seca stream (SP) & 50 & $\operatorname{Rex} 1 / \operatorname{Rex} 6$ & Dispersed & 4 \\
\hline & & & $\operatorname{Rex3}$ & Clustered & 4 \\
\hline & Capivara river (SP) & 50 & $\operatorname{Rex} 1 / \operatorname{Rex} 6$ & Dispersed & 4 \\
\hline & & & Rex3 & Clustered & 4 \\
\hline A. altiparanae & & 50 & $\operatorname{Rex} 1$ & Scattered & PS \\
\hline A. asuncionensis & & 50 & $\operatorname{Rex} 1$ & Scattered & PS \\
\hline A. eigenmanniorum & & 50 & $\operatorname{Rex} 1$ & Scattered & PS \\
\hline A. marionae & & 48 & $\operatorname{Rex} 1$ & Scattered & PS \\
\hline A. fasciatus & & 46 & $\operatorname{Rex} 1$ & Scattered & PS \\
\hline A. schubarti & & 36 & $\operatorname{Rex} 1$ & Scattered & PS \\
\hline
\end{tabular}

*1 - Pansonato-Alves et al. (2013); 2 - Silva et al. (2013); 3 - Silva et al. (2014); 4 - Daniel et al. (2015). Abbreviations: B, presence of B chromosome; Kary.,

karyomorph; SP, São Paulo state; PS, present study; Ref., references.

found in small clusters and dispersed, both on heterochromatic and euchromatic regions (Ferreira et al. 2011).

These retrotransposable elements are also found on heterochromatic regions of fish chromosomes (Bouneau et al. 2003; Fischer et al. 2004; Mazzuchelli and Martins 2009; Teixeira et al. 2009; Valente et al. 2011). The explanations for this pattern is that these elements may accumulate on sites of low recombination rates and coding functions, in order to avoid deleterious effects if inserted within genes, or as a consequence of their role in regulating specific regions, such as pericentromeric and telomeric sites (Valente et al. 2011).

The differences between Rex elements localizations may reflect distinct evolutionary factors guiding these 
sequence distributions. However, it is also not possible to rule out the effects of distinct hybridization conditions employed in the experiments from different studies, such as high-stringency conditions that might mask the signals (Ferreira et al. 2011).

After analyzing our studies and comparing them with others already existing in the literature we can consider that Rex 1 is dispersed and Rex 3 is clustered in the Astyanax species. These retrotransposons may play an important role in genome evolution.

\section{Acknowledgments}

The authors are grateful to Dr. Leonardo Marcel Paiz and MSc. Rafael Splendore de Borba for their assistance in aligning DNA sequences.

\section{Disclosure statement}

No potential conflict of interest was reported by the authors.

\section{Funding}

Fundação de Amparo a Pesquisa do Estado de São Paulo (FAPESP) provided financial support [process number: 2011/07457-0].

\section{References}

Biemont C, Vieira C. 2006. Genetics: junk DNA as an evolutionary force. Nature. 443:521-524.

Bohne A, Brunet F, Galiana-Arnoux G, Schultheis C, Volff JN. 2008. Transposable elements as drivers of genomic and biological diversity in vertebrates. Chromosome Res. 16:203-215.

Borba RS, Silva EL, Parise-Maltempi PP. 2013. Chromosome mapping of retrotransposable elements Rex 1 and Rex3 in Leporinus Spix, 1829 species (Characiformes: Anostomidae) and its relationships among heterochromatic segments and W sex chromosome. Mob Genet Elements. 3:e27460.

Bouneau L, Fischer C, Ozouf-Costaz C, Froschauer A, Jaillon O, Coutanceau JP, Korting C, Weissenbach J, Bernot A, Volff JN. 2003. An active non-LTR retrotransposon with tandem structure in the compact genome of the pufferfish Tetraodon nigroviridis. Genome Res. 13:1686-1695.

Cabral-de-Mello DC, Moura RC, Martins C. 2010. Chromosomal mapping of repetitive DNAs in the beetle Dichotomius geminatus provides the first evidence for an association of $5 \mathrm{~S}$ rRNA and histone $\mathrm{H} 3$ genes in insects, and repetitive DNA similarity between the B chromosome and A complement. Heredity. 104:393-400.

Daniel SN, Penitente M, Silva DM, Hashimoto DT, Ferreira DC, Foresti F, Porto-Foresti F. 2015. Organization and Chromosomal Distribution of Histone Genes and Transposable Rex Elements in the Genome of Astyanax bockmanni (Teleostei, Characiformes). Cytogenet Genome Res. 146:311-318.

Ferreira DC, Oliveira C, Foresti F. 2011. Chromosome mapping of retrotransposable elements Rex 1 and Rex3 in three fish species in the subfamily Hypoptopomatinae (Teleostei, Siluriformes, Loricariidae). Cytogenet Genome Res. 132:64-70.
Feschotte C, Pritham EJ. 2007. DNA transposons and the evolution of eukaryotic genomes. Annu Rev Genet. 41:331-368.

Fischer C, Bouneau L, Coutanceau JP, Weissenbach J, Volff JN, Ozouf-Costaz C. 2004. Global heterochromatic colocalization of transposable elements with minisatellites in the compact genome of the pufferfish Tetraodon nigroviridis. Gene. 336:175-183.

Foresti F, Oliveira C, Foresti de Almeida-Toledo L. 1993. A method for chromosome preparations from large fish specimens using in vitro short-term treatment with colchicine. Experientia. 49:810-813.

Hall TA. 1999. BioEdit: a user-friendly biological sequence alignment editor and analysis program for Windows 95/98/NT. Nucl Acids Symp Ser. 41:95-98.

Kazazian HH, Moran JV. 1998. The impact of L1 retrotransposons on the human genome. Nat Genet. 19:19-24.

Mazzuchelli J, Martins C. 2009. Genomic organization of repetitive DNAs in the cichlid fish Astronotus ocellatus. Genetica. 136:461-469.

Nishiyama PB, Vieira MM, Porto FE, Borin LA, PortelaCastro AL, Santos IC. 2016. Karyotypic diversity among three species of the genus Astyanax (Characiformes: Characidae). Braz J Biol. 76:360-366.

Ozouf-Costaz C, Brandt J, Körting C, Pisano E, Bonillo C, Coutanceau JP, Volff JN. 2004. Genome dynamics and chromosomal localization of the non-LTR retrotransposons Rex1 and Rex3 in Antarctic fish. Antarct Sci. 16:51-57.

Pansonato-Alves JC, Hilsdorf AW, Utsunomia R, Silva DM, Oliveira C, Foresti F. 2013. Chromosomal mapping of repetitive DNA and cytochrome $\mathrm{C}$ oxidase I sequence analysis reveal differentiation among sympatric samples of Astyanax fasciatus (Characiformes, Characidae). Cytogenet Genome Res. 141:133-142.

Pinkel D, Straume T, Gray JW. 1986. Cytogenetic analysis using quantitative, high-sensitivity, fluorescence hybridization. Proc Natl Acad Sci U S A. 83:2934-2938.

Piscor D, Parise-Maltempi PP. 2016a. Chromosomal mapping of $\mathrm{H} 3$ histone and 5S rRNA genes in eight species of Astyanax (Pisces, Characiformes) with different diploid numbers: syntenic conservation of repetitive genes. Genome. 59:167-172.

Piscor D, Parise-Maltempi PP. 2016b. Microsatellite Organization in the B Chromosome and A Chromosome Complement in Astyanax (Characiformes, Characidae) Species. Cytogenet Genome Res. 148:44-51.

Piscor D, Alves AL, Parise-Maltempi PP. 2015. Chromosomal microstructure diversity in three Astyanax (Characiformes, Characidae) species: comparative analysis of the chromosomal locations of the $18 \mathrm{~S}$ and $5 \mathrm{~S}$ rDNAs. Zebrafish. 12:81-90.

Piscor D, Centofante L, Parise-Maltempi PP. 2016. Highly Similar Morphologies Between Chromosomes Bearing U2 snRNA Gene Clusters in the Group Astyanax Baird and Girard, 1854 (Characiformes, Characidae): An Evolutionary Approach in Species with $2 \mathrm{n}=36,46,48$, and 50. Zebrafish. 13:565-570.

Sambrook J, Russell DW. 2001. Molecular cloning: a laboratory manual. New York, NY: Cold Spring Harbor Laboratory Press; p. 2100.

Silva DM, Pansonato-Alves JC, Utsunomia R, Daniel SN, Hashimoto DT, Oliveira C, Porto-Foresti F, Foresti F. 2013. Chromosomal organization of repetitive DNA sequences in Astyanax bockmanni (Teleostei, Characiformes): dispersive location, association and co-localization in the genome. Genetica. 141:329-336. 
Silva DM, Pansonato-Alves JC, Utsunomia R, Araya-Jaime C, Ruiz-Ruano FJ, Daniel SN, Hashimoto DT, Oliveira C, Camacho JP, Porto-Foresti F, Foresti F. 2014. Delimiting the origin of a B chromosome by FISH mapping, chromosome painting and DNA sequence analysis in Astyanax paranae (Teleostei, Characiformes). PLoS One. 9: e94896.

Teixeira WG, Ferreira IA, Cabral-de-Mello DC, Mazzuchelli J, Valente GT, Pinhal D, Poletto AB, Venere PC, Martins C. 2009. Organization of repeated DNA elements in the genome of the cichlid fish Cichla kelberi and its contributions to the knowledge of fish genomes. Cytogenet Genome Res. 125:224-234.

Tenório RC, Vitorino CA, Souza IL, Oliveira C, Venere PC. 2013. Comparative cytogenetics in Astyanax (Characiformes: Characidae) with focus on the cytotaxonomy of the group. Neotrop Ichthyol. 11:553564.
Valente GT, Mazzuchelli J, Ferreira IA, Poletto AB, Fantinatti BE, Martins C. 2011. Cytogenetic mapping of the retroelements Rex1, Rex3 and Rex6 among cichlid fish: new insights on the chromosomal distribution of transposable elements. Cytogenet Genome Res. 133:34-42.

Volff JN, Korting C, Sweeney K, Schartl M. 1999. The nonLTR retrotransposon Rex3 from the fish Xiphophorus is widespread among teleosts. Mol Biol Evol. 16:1427-1438.

Volff JN, Korting C, Schartl M. 2000. Multiple lineages of the non-LTR retrotransposon Rexl with varying success in invading fish genomes. Mol Biol Evol. 17:1673-1684.

Volff JN, Korting C, Froschauer A, Sweeney K, Schartl M. 2001. Non-LTR retrotransposons encoding a restriction enzyme-like endonuclease in vertebrates. J Mol Evol. 52:351-360.

Volff JN, Bouneau L, Ozouf-Costaz C, Fischer C. 2003. Diversity of retrotransposable elements in compact pufferfish genomes. Trends Genet. 19:674-678. 